\title{
Internet of Things Business Model Innovation and the Stage-Gate Process: An Exploratory Analysis
}

Article in International Journal of Innovation Management · May 2017

DOI: $10.1142 / \mathrm{S} 1363919617400023$

CITATIONS

3

3 authors:

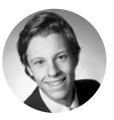

\section{Jan Tesch}

Robert Bosch GmbH

10 PUBLICATIONS 16 CITATIONS

SEE PROFILE

Dominik Bilgeri

ETH Zurich

8 PUBLICATIONS 20 CITATIONS

SEE PROFILE
READS

313
Anne-Sophie Brillinger

Katholische Universität Eichstätt-Ingolstadt (... 2 PUBLICATIONS 3 CITATIONS

SEE PROFILE

Some of the authors of this publication are also working on these related projects: 


\title{
IoT Business Model Innovation and the Stage-Gate Process: an exploratory analysis
}

\author{
Jan F. Tesch* \\ University of Göttingen, Platz der Göttinger Sieben 5, 37073 \\ Göttingen, Germany \\ E-Mail: mail@jan-tesch.de
}

\author{
Anne-Sophie Brillinger \\ Catholic University Eichstaett-Ingolstadt, Auf der Schanz 49, 85049 \\ Ingolstadt, Germany \\ E-Mail: anne.brillinger@ku.de
}

\section{Dominik Bilgeri}

ETH Zürich, Weinbergstraße 56/58, 8092 Zürich, Switzerland

E-mail: dbilgeri@ethz.ch

* Corresponding author

\begin{abstract}
Large manufacturing companies will in future be continuously challenged to develop and implement new IoT-related business models. Existing research offers interesting insights on high-level stages of business model innovation (BMI) processes in general. However, only little is known about the presence of main gates in BMI processes and even less about the underlying decision criteria applied at these gates. To shed more light on this research field, 27 expert interviews with employees from eight companies across the IoT ecosystem were conducted. The expert interviews reveal that, despite the increasing popularity of (radically) new innovation approaches, two main decision points can be identified across BMI processes. These findings are a first explorative step towards a better understanding of IoT adoption and provide a starting point for interesting future research avenues.
\end{abstract}

Keywords: Internet of Things; Business Model Innovation; Stage-Gate System; Case Study Research

\section{Introduction}

Large manufacturing companies across industries, such as General Electric (GE) and others, got recently under severe pressure, facing new fields of competition from nontraditional market players such as IBM, SAP or data analytics startups (Iansiti and Lakhani, 2014). Rather than supplying resilient industry equipment these non-traditional 
competitors focus on new opportunities arising from the Internet of Things (IoT) and "deriving new efficiencies and other benefits through advanced analytics and algorithms based on the data generated by that equipment" (Iansiti and Lakhani, 2014, p. 91). In order not to miss out on these new fields of competition, in particular the promising areas of data and service monetization, large manufacturing companies will in future be continuously challenged to develop and implement IoT related business models (Chesbrough, 2010; Iansiti and Lakhani, 2014). While companies generally struggle to innovate their business models, BMI in an IoT context is subject to some additional hurdles, posing an even greater challenge to manufacturing companies to realize successful IoT BMI projects (Bilgeri and Wortmann, 2017). Thereby, current literature offers only limited insights on how to operationalize IoT business model innovation (Schneider and Spieth, 2013).

Several practitioners contributed interesting, new innovation approaches to this research stream. Increasingly popular concepts include highly iterative approaches such as lean-start-up, agile, effectuation or design thinking (Blank, 2013; Liedtka, 2015; Ries, 2011; Sarasvathy, 2001). At the same time, scholars disagree on how to adequately design business model innovation processes (Frankenberger et al., 2013). They specifically debate, how to evaluate such new approaches in light of so far widely implemented, structured launch-to-idea processes such as the Stage-Gate system (Cooper, 2008). Hence, it remains unclear to what extent companies also in an IoT era still rely on main go/kill decisions as suggested in traditional innovation process literature.

Existing research on business model innovation to date offers interesting insights on high-level stages of BMI processes in general (Frankenberger et al., 2013; Teece, 2010), however, only little is known about the presence of main gates across IoT specific BMI processes and even less about the underlying decision criteria applied at these gates. To shed more light on the depicted research gap, this study seeks to identify the main decision gates in IoT business model innovation. More specifically, our research aims to address the following two research questions (RQ):

\section{RQ1: What are the main gates currently applied in IoT business model innovation?}

\section{RQ2: What criteria are applied to make decisions at each gate?}

In total, 27 expert interviews with employees from eight companies across the IoT ecosystem were conducted. The findings reveal that, despite the increasing implementation of (radical) new innovation approaches within their companies, two fundamental decision points can be identified across BMI processes. The first main gate, predominantly utilizing qualitative data, refers to the decision, whether or not to test a business model sketch. At the second main gate, then management has to decide based on more quantified data, whether to scale the business model. These findings provide a starting point for interesting future research avenues, including the question, how the overall basis for decision making in BMI processes can be improved and how related risks could be addressed.

\section{Theoretical background}

In light of the research questions addressed in this study, the following subchapters briefly outline the four key concepts 'Internet of Things', 'business models', business model innovation' and the 'Stage-Gate system'. Thus, this section provides the theoretical foundation and defines the scope of the research. 


\subsection{Internet of Things}

The term 'Internet of Things' was originally coined at the Auto-ID Lab at the Massachusetts Institute of Technology (MIT) (Atzori et al., 2010; Mattern and Floerkemeier, 2010). It describes a broader vision of a worldwide IT infrastructure merging the physical with the digital word (Miorandi et al., 2012; Vermesan et al., 2013). As part of this vision, virtually all objects are predicted to become intelligent - i.e. capable to use sensor and actuator technology to gather data as well as to communicate with each other and the online world (Atzori et al., 2010; Fleisch et al., 2015). A growing number of such connected devices encourages companies across industries to identify Internet of Things technologies and related revenue potential as a top priority (Porter and Heppelmann, 2015). Business opportunities arising from such IoT technologies are versatile and reach across industries (Porter and Heppelmann, 2015; Arnold et al., 2016), including such diverse application fields like mobility, health or smart home (Atzori et al., 2010). Such new business opportunities pose major challenges to manufacturing companies (Mattern and Flörkemeier, 2010; Porter and Heppelmann, 2015). Organizations often lack the necessary competencies to compete in these new markets, since offering IoT solutions significantly deviates from their core business. Therefore, the IoT is assumed to come along with some specific technical as well as business-related new challenges (Bilgeri and Wortmann, 2017). The most critical technical difficulties include an absence of protocol standardization, scalability limits or energy supply (Atzori et al., 2010; Mattern and Flörkemeier, 2010). Besides this technical research stream, various papers investigate the new business-related challenges to IoT (Cavalcante, 2014; Chesbrough, 2010). Examples for such hurdles include complex business ecosystems, lack of data analytic skills or unfamiliar means of revenue generation - in sum, the design of appropriate IoT business models (Laudien and Daxböck, 2016b; Frankenberger et al., 2013; Koen et al., 2011).

\subsection{Business Models}

Initially, the term 'business model' was introduced as a buzzword in the popular press some 20 years ago (Demil and Lecocq, 2010; Magretta, 2002). Therefore, the related research connected to this relatively young concept is still in an early stage (Landau et al., 2016). Despite the increasing attention it receives from scholars and practitioners alike, no shared business model definition emerged so far (Baden-Fuller and Morgan, 2010; Wirtz et al., 2010; Zott et al., 2011). Following a common high-level understanding, business models describe "both value creation and value capture" (Zott et al., 2011, p. 1020) and explain "how the pieces of a business fit together" (Magretta, 2002, p. 91). Two different, yet complementary research streams dominate the on-going debate about the conceptualization of business models (Landau et al., 2016). On the one hand, according to the "value-based perspective', business models describe "the logic [...] that demonstrates how a business creates and delivers value to customers." (Teece, 2010, p. 173). More specifically, business models are assumed to "outline the architecture of revenues, costs, and profits associated with the business enterprise delivering that value" (Teece, 2010, p. 173). On the other hand, following the seminal article of Zott and Amit (2009, p. 1), the 'activity system perspective' depicts a business model as "a system of interdependent activities that transcends the focal firm and spans its boundaries". In line with the activity system perspective business models contain the content (the goods exchanged as well as the capabilities and resources required 
to do so), structure (involved stakeholders and their relationships), and governance (control of flows of goods, resources and information) of transactions. (Amit and Zott, 2001).

\subsection{Business Model Innovation}

A transformational perspective on business models, e.g. triggered by new technological means, is at the core of business model innovation (Cortimiglia et al., 2016). The research stream on business model innovation is still very young and no clear understanding of what BMI incorporates exists (Schneider and Spieth, 2013). As an umbrella term, the concept describes companies' efforts related to "the search for new [business] logics of the firm and new ways to create and capture value for its stakeholders" (Casadesus-Masanell and Zhu, 2013, p. 464). Such a definition incorporates both, the "modification, reconfiguration and extension [...] of existing business models" (business model development) as well as the design of "fundamentally new and sometimes disruptive" business models (business model design) (Landau et al. 2016, p. 3; Cortimiglia et al., 2016; Markides, 2006). Against the research questions addressed in this study, both approaches are considered as BMI (Cortimiglia et al., 2016). So far the knowledge about BMI processes is limited (Schneider and Spieth, 2013). Several early studies elaborate on business model innovation processes, including Teece (2010), Laudien and Daxböck (2016a) and Frankenberger et al. (2013). However, to the best of our knowledge, no empirical studies have yet addressed business model innovation processes in greater depth. While there are very recent studies starting to base their research findings on case study data (Laudien and Daxböck, 2016a), previous papers on BMI processes (Frankenberger et al., 2013) provide mainly anecdotal evidence. All these studies present different BMI process models and concentrate on the best means to conceptualize and design BMI phases. Thereby, the identified BMI phases deviate with regard to their number, terminology, set of performed activities and sequence. In addition, focusing on phases, these papers only pay little attention towards the main decision points and underlying decision criteria within innovation processes (cf. Laudien and Daxböck, 2016a). In light of the limited research on BMI processes (Schneider and Spieth, 2013), academics agree that the related, yet much richer research stream on new product development (NPD) is most suited to inform BMI research (Chesbrough, 2010). A popular idea-to-launch process widely implemented in the field of new product development, but also various other types of business processes, is the Stage-Gate system (Cooper, 2008).

\subsection{Stage-Gate System}

The Stage-Gate system describes a prototypical innovation process consisting of different stages (sets of activities) separated by gates (decision points) (Cooper, 2008). Thereby, the system which was originally introduced in the 1980s, has been challenged by current iterative needs and approaches (e.g. agile development, open innovation, lean start-up, design thinking) (Cooper, 2014). As a result, Stage-Gate has been further advanced and adapted to be used complementary to such methodologies (Cooper, 2014). For the purpose of this study, the Stage-Gate system offers a coherent and widely acknowledged conceptualization of two important notions, namely 'gates' and 'stages' (Cooper, 2008). In line with Cooper's most recent understanding of the concepts, stages and gates are defined as follows (Cooper, 2014). 
Stages are seen as "a set of best-practice activities needed to progress the project to the next gate or decision point" (Cooper, 2008, p. 215). The purpose of each stage can be determined by the information that are gathered, aiming to reduce projects main uncertainties and risks. Thereby, the activities associated with each stage are project specific and conducted simultaneously by cross-functional teams across business units (Cooper, 2008). While with each stage project costs increase, the "unknowns and uncertainties are driven down so that risk is effectively managed" (Cooper, 2008, p. 215).

Gates following stages "are go/kill and prioritization decision points, [...] where the path forward for the next stage of the project is agreed to" (Cooper, 2008, p. 215). Gates can be characterized by three main features: deliverables (the 'results' of the previous stage building the basis for decision making), criteria (questions and indicators against which the innovation project is evaluated) and outputs (decisions about prioritization of specific project aspects or general go/kill decisions) (Cooper, 2008). Analogous to stages, a gate's design is project specific and its due date can be rescheduled depending on the current project saturation (Cooper, 2014).

\section{Research design}

This study is a first attempt to analyze IoT-based business model innovations and their development process, focusing on the relevant decision points and decision criteria. To reach this goal, the research team chose a qualitative multiple-case study approach, primarily based on semi-structured interviews (Eisenhardt, 1989; Yin, 1981, 2014; Miles and Huberman, 1994). A qualitative research approach seems appropriate to analyze IoTbased business model innovations and their development process. It facilitates collecting data which naturally occurs and is recommendable for doing research on complex processes in real-life settings (Eisenhardt and Graebner, 2007; Gephart, 2004; Günzel and Holm, 2013; Langley, 1999; Denzin and Lincoln, 2000). A multiple-case study approach was chosen to improve the generalizability across different business models and organizations and to allow cross-case analysis (Benbasat et al., 1987; Eisenhardt and Graebner, 2007; Yin, 2013). Besides, several case studies help to improve external validity and to mind observer bias (Leonard-Barton, 1990, 1992).

\subsection{Research Setting}

The authors selected 13 cases from eight different companies. By this number data saturation was reached, since the marginal gain of information of every additional case became minimal and a generalizability across cases could be achieved by this sample size (Eisenhardt, 1989; Leonard-Barton, 1990). Case studies were chosen according to their suitability for the study, based on the following criteria: 1) the cases fulfill all aspects of being a 'business model innovation' according to the definition of this paper; 2) the selected project is a business model innovation in the IoT context; 3) Case firms are established companies across the IoT ecosystem; 4) interview participants are experts from different functions / positions in IoT business model innovations (cf. Laudien and Daxböck, 2016b). In the run-up to the interviews, these criteria were checked in a first phone call, via email and on the company's websites. 


\subsection{Data collection}

In total 27 experts, highly experienced in IoT business model innovation, from different positions and functions were interviewed to secure data triangulation. Three independent researchers analyzed the data to also ensure investigator triangulation (Blaikie, 1991; Denzin and Lincoln, 2000). Participants were first contacted via phone or email and informed about the research project. Then, they were asked to give some information about their position, department and project in order to check the underlying criteria of the interview participation. After, semi-structured face-to-face interviews were carried out in order to get good-quality data (Koh et al., 2011). Yet, due to accessibility constraints, a few interviews had to be conducted on the phone. Interviews took between 30 and 60 minutes. All interviews were based on structured and detailed interview guidelines, created of relevant literature before the data collection and reviewed during the collection phase (Schnell et al., 2014). Interviews were tape-recorded and fully transcribed to achieve consensus, accuracy and completeness of the data (Harmancioglu et al., 2007). For securing research ethics, all interviews were fully made anonymous (Kuckartz, 2012; Miles and Huberman, 1994). Table 1 gives an overview of the cases and the relating interview partners. For securing high anonymity, only minimal information about the projects, firms and employees is provided ${ }^{1}$. Apart from the interviews, archival data, such as presentations, reports and field notes, were collected to ensure data triangulation (Blaikie, 1991; Denzin and Lincoln, 2000).

\subsection{Data analysis}

After the data collection, the three researchers independently analyzed the data. First, cases were separately described in a report and then compared in a cross-case analysis (Brown and Eisenhardt, 1997; Eisenhardt, 1989; Miles and Huberman, 1994; Yin, 2013). In the reports, cases were individually summarized based on their characteristics. Then, the transcripts were analyzed according to the items and categories of the interview guidelines. In each case the main decision points were identified and the mentioned decision criteria were aligned to the decision points. After, the decision criteria were categorized into rather qualitative, soft aspects and rather quantitative, objective aspects. Finally, the results of each individual case were compared in a cross-case analysis (Brown and Eisenhardt, 1997; Eisenhardt, 1989; Miles and Huberman, 1994; Yin, 2013).

\footnotetext{
${ }^{1}$ Further details may be obtained from the authors upon request.
} 
Table 1 List of case studies and interview partners

\begin{tabular}{|c|c|c|c|c|}
\hline Case & Industry* & $\begin{array}{l}\text { Project } \\
\text { description }\end{array}$ & $\begin{array}{l}\text { Interviews } \\
\text { (Partners) }\end{array}$ & $\begin{array}{l}\text { Roles of } \\
\text { interview partners }\end{array}$ \\
\hline 1 & Consultancy & $\begin{array}{l}\text { Diverse IoT BMI consultant } \\
\text { projects across industries }\end{array}$ & $3(3)$ & $\begin{array}{l}\text { Manager; } \\
\text { Senior Consultant; } \\
\text { Consultant }\end{array}$ \\
\hline 2 & $\begin{array}{l}\text { Technology } \\
\text { company }\end{array}$ & Platform business model & $2(2)$ & $\begin{array}{l}\text { Head of New Business } \\
\text { Development; } \\
\text { Project Manager in New } \\
\text { Business Development }\end{array}$ \\
\hline 3 & $\begin{array}{l}\text { Technology } \\
\text { company }\end{array}$ & Telematic freight system & $2(2)$ & $\begin{array}{l}\text { Project Manager; } \\
\text { Product Manager }\end{array}$ \\
\hline 4 & $\begin{array}{l}\text { Software } \\
\text { company }\end{array}$ & IoT software platform & $3(3)$ & $\begin{array}{l}\text { Senior Consultant; } \\
\text { Business Development } \\
\text { Manager; } \\
\text { Product Owner }\end{array}$ \\
\hline 5 & $\begin{array}{l}\text { Technology } \\
\text { company; } \\
\text { University }\end{array}$ & $\begin{array}{l}\text { BMI of IoT solution in the } \\
\text { smart living industry }\end{array}$ & $2(2)$ & $\begin{array}{l}\text { Portfolio Manager; } \\
\text { Research consultant } \\
\text { (Professor) }\end{array}$ \\
\hline 6 & $\begin{array}{l}\text { Technology } \\
\text { company }\end{array}$ & Smart on board system & $2(2)$ & $\begin{array}{l}\text { Member of the } \\
\text { management board; } \\
\text { Head of product and } \\
\text { market development }\end{array}$ \\
\hline 7 & Consultancy & Automated data center & $2(2)$ & $\begin{array}{l}\text { Head of Consulting; } \\
\text { Technical project manager }\end{array}$ \\
\hline 8 & $\begin{array}{l}\text { Technology } \\
\text { company }\end{array}$ & $\begin{array}{l}\text { Automated customer } \\
\text { validation for mobility } \\
\text { services }\end{array}$ & $2(2)$ & $\begin{array}{l}\text { Head of start-up incubator; } \\
\text { CEO of a corporate start-up }\end{array}$ \\
\hline 9 & $\begin{array}{l}\text { Technology } \\
\text { company }\end{array}$ & $\begin{array}{l}\text { Software solution for } \\
\text { connected power tools } \\
\text { management }\end{array}$ & $2(3)$ & $\begin{array}{l}\text { Project Managers; } \\
\text { Senior Product Manager }\end{array}$ \\
\hline 10 & $\begin{array}{l}\text { Technology } \\
\text { company }\end{array}$ & $\begin{array}{l}\text { Newly introduced smart } \\
\text { healthcare solution }\end{array}$ & $2(2)$ & $\begin{array}{l}\text { Business Development } \\
\text { Manager; } \\
\text { Strategy \& New Business } \\
\text { Development }\end{array}$ \\
\hline 11 & $\begin{array}{l}\text { Technology } \\
\text { company }\end{array}$ & $\begin{array}{l}\text { Dynamic process and } \\
\text { inventory management for } \\
\text { construction sites }\end{array}$ & $1(2)$ & $\begin{array}{l}\text { Head of Department; } \\
\text { Marketing Manager }\end{array}$ \\
\hline 12 & $\begin{array}{l}\text { Mobility } \\
\text { provider }\end{array}$ & $\begin{array}{l}\text { BMI to utilize new } \\
\text { technologies for internal } \\
\text { operation purposes }\end{array}$ & $1(1)$ & $\begin{array}{l}\text { Senior Consultant in } \\
\text { Business Development }\end{array}$ \\
\hline 13 & $\begin{array}{l}\text { Technology } \\
\text { company }\end{array}$ & Diverse IoT BMI projects & $1(1)$ & Senior R\&D Manager \\
\hline
\end{tabular}




\section{Findings}

In order to meet new fields of competition, arising in an IoT context, the large majority of companies in our sample emphasized the demand for more iterative innovation approaches, compared to so far established sequential innovation frameworks (such as Stage Gate) to successfully develop IoT business models. More precisely, various interview partners referred to the necessity for continuous trial-and-error procedures, resulting from higher degrees of complexity and uncertainty in an IoT context. This stems from the fact that companies often initiate a BMI process triggered by strategical considerations upon the development of capabilities and key resources as potential competitive advantages in the future. Overall, the analysis revealed deviating modes of how to pursue business model innovation, individual for each of the 13 cases.

According to our interview partners, a multitude of minor, preliminary decisions have to be made continuously in the innovation processes. Hereby, the decision makers face in the light of new IoT solutions - an increased amount of uncertainty and a lack of transparency of potential consequences. Among others, the choice of potential business partners, the organizational structure, the physical project location or the technical realization of the product are just a few examples. All case companies reported, that later in the timeline, some situations forced the BM innovation management to revise previous decisions. These, in the first place, appeared to be minor as they only affected a partial aspect of the business model, such as key partners. In contrast, in some cases, this practice interfered with the focal firm's ability to build a value proposition that addressed the customer's corresponding willingness to pay. Hence, the revision of an earlier initial decision led to an offset of other later, mutually dependent decisions. A view on this through the lens of gates and stages, shows that BMI project managers are forced 'to skip back and forth' within different stages. The BM innovation projects were 'set-back' and were required to 'reiterate', until all interrelating aspects of the business model sketch were saturated enough to make investment decision criteria transparent and tangible. For all analyzed cases, R\&D-management therefore often allowed to develop the BM with bypassing some stages, gates and decision templates. In light of these shortcomings, traditional, so far strictly implemented, idea-to-launch processes were perceived to be outdated to adequately innovate new, potentially disrupting IoT business models.

Nevertheless, irrespective of the iterative and flexible approaches employed, we identified two major decision points that flag a 'point of no return'. Thus, these may characterize 'gates', when analyzing the business model innovation process through a lens corresponding to the original understanding of Cooper.

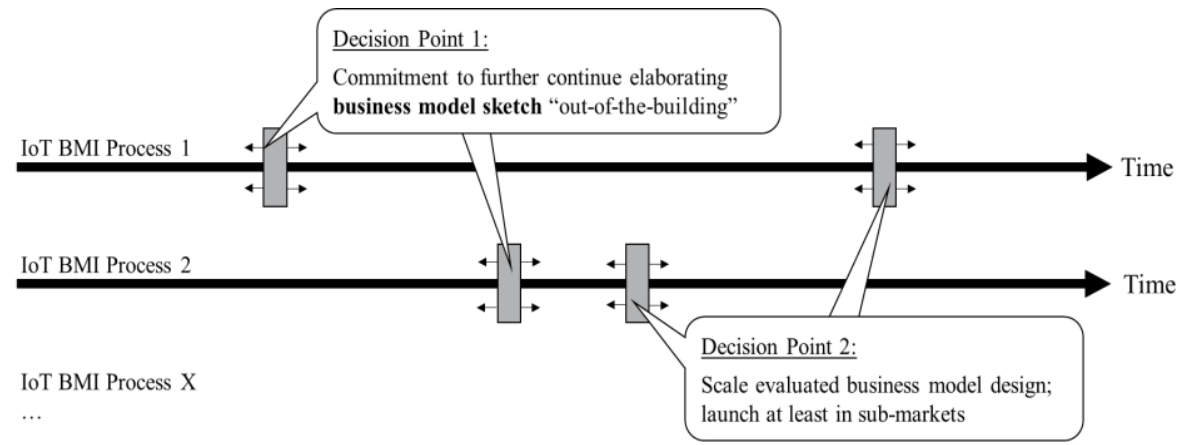

Figure 1 Two decision points and their occurrence on the BMI timeline. 
The first major gate may be referred to as a decision whether to release the necessary budget to evaluate a business model sketch through a proof of concept (PoC) prototype, allowing for immediate customer interaction. Prior to this, the elaboration and evaluation of the business model idea rather focuses on analytical work. The decision criteria include the consideration of the overall financial viability of the BM. Further, decision makers consider a sketched plan on how to deal with uncertainties, such as a yet unclear willingness-to-pay for a novel value proposition. Generally, the companies from our sample aimed to objectify unclear information for a decision base. This can be regarded as an endeavor to predict future market conditions, technological prerequisites or business logics in the surrounding industry. Means to gather information, e.g., included voting in workshops, balanced scorecards, metrics, structured interviews with technology/industry experts or other methodologies. However, evaluation activities come to a saturation point, where further analytical work does not significantly lead to a more consistent decision base. At this point, it is crucial to continue the innovation of the business model with prototyperelated means of elaboration and evaluation. Since several aspects of the future viability of the business model remain vague, the decision-making of management or investors is often driven by rather social skills of the project lead, such as the ability of good storytelling of obtained, rather qualitative information.

Table 2 Two main decision points and underlying criteria

\begin{tabular}{|c|c|}
\hline $\begin{array}{l}\text { Decision point 1: } \\
\text { Commitment to test BM sketch }\end{array}$ & $\begin{array}{l}\text { Decision point 2: } \\
\text { Decision to scale business model }\end{array}$ \\
\hline $\begin{array}{l}\text { Subjective interpretation of qualitative } \\
\text { criteria }\end{array}$ & $\begin{array}{l}\text { Results from various tests of assumptions } \\
\text { underlying the business model sketch }\end{array}$ \\
\hline $\begin{array}{l}\text { Exemplary criteria applied: } \\
\text { - } \quad \text { Possession of core competencies / } \\
\text { dynamic capabilities } \\
\text { - } \text { Fit with strategic roadmap of the } \\
\text { corporation } \\
\text { - Potential customer demand } \\
\text { - } \text { Interest of external stakeholders } \\
\text { - } \text { Alignment with market trends } \\
\text { - } \text { Benchmark with competitors } \\
\text { - } \text { Level of uncertainty / risk } \\
\text { - } \text { Rough financial estimates are likely } \\
\text { to meet investment expectations }\end{array}$ & $\begin{array}{l}\text { Exemplary criteria applied: } \\
\text { - Successful prototyping and customer } \\
\text { interaction } \\
\text { - Results from field tests / customer } \\
\text { surveys } \\
\text { - Commitment of stakeholders and key } \\
\text { partners } \\
\text { - Viable business case calculations } \\
\text { - Business model risk evaluation } \\
\text { - Significant customer demand is } \\
\text { - identified }\end{array}$ \\
\hline
\end{tabular}

The second decision point refers to a decision whether to commit the organization to the implementation and rollout of the business model with all risks involved. In order to be prepared for the decision at gate two, the budget released at gate one is used to finance the development of a proof-of-concept business model prototype. Thereby, in the phase between gate one and gate two the business model is continuously tested and adapted in an iterative setting. Furthermore, it is elaborated until iteration cycles do not lead to any increase of the integrity of information. This decision base for the second gate considers e.g. risk evaluation, scenarios, roadmaps, customer surveys or field tests that aim to 
quantify the findings. Tools that gather information have a more quantitative focus, as they may directly reflect suppliers, partners and customer's opinion on tangible components of the business model. This helps to strengthen financial profit and loss estimations to become more precise and bear less uncertainty. Despite gate 2 being more quantitative than gate 1 , we often found that one cannot fully describe all effects and outcomes of a deployed business model before a real market role out. Our case studies reveal that investors or managerial boards for the IoT innovation projects still had to base their decision at the second gate on less certain factors, and a higher degree of risk, when compared to earlier economic paradigms. These risks - amongst others - stemmed from difficulties to handle organizational obstacles or orchestrating the interplay of complementary customer groups and partners.

Despite the occurrence of the two characterizing decision points, their distance and their occurrence on a timeline shift is individual for each case. Activities before the decisions generally do not follow a sequenced procedure, even though when proposed by a general innovation framework of the overarching organization. Pursued activities as well as their logical meaningfulness diverge from case to case. They are continuously iterated, primarily due to the complexity of BMI endeavor in an IoT context. This reveals different perspectives on the business model design and thus adds to a more viable decision base. The activities are pursued until the integrity of additional information is saturated. Thereby, we found that the actual timing of the decision points is individual for each case. Factors that primarily drive the required time for the 'decision-readiness' are: a. the innovation trigger of the project (e.g. technology push vs. market pull); b. the degree of digitalization of the business model; c. the degree of the novelty of the BM's value proposition; $d$. the industry and e. the prototypical pattern of the core business model logic.

\section{Discussion}

Structured idea-to-launch processes represent a viable approach within classical new product development (NPD). Especially when the complexity of the product or service under development requires the collaboration of experts from different disciplines to work together, a sequential process helps to orchestrate activities of individuals involved. For instance, the stage-gate process (Cooper, 2008) provides chronological guidance, which allows for sequenced activities to be adequately managed. However, our findings show that the features and outcomes do not hold for the paradigm of holistic business model innovation, especially in connection with the digital transformation of manufacturing companies as investigated. This finding particularly applies with an increasing amount of interdependencies of business model components, involved external stakeholders in a value network, and multi-sided-platform effects occurring in the IoT era. These factors are identified as stereotypical in IoT BMI projects (Westerlund et al., 2014).

The findings provide evidence that, across the diversity of IoT business model innovation projects investigated, all cases share the occurrence of two gates as major go/kill or prioritization decisions. These gates share alike decision criteria and occurred regardless of the different (iterative) innovation frameworks and approaches applied. Traditional approaches often serve as initial innovation guidance for practitioners. However, when critically reflecting the process ex-post, they often report constant deviation from these approaches, as for example expressed by the multiple postponements of decision points by the management boards in our case companies. 
Strategic considerations on the companies' capabilities and resources often serve as a trigger for the initiation of a BMI-process in the IoT paradigm. Thereby, key mutually depending components of the business model, such as customer groups, corresponding value propositions or the necessary collaboration with stakeholders, evolve over time, rather following a trial-and-error logic than a traditional sequential process. Popular approaches, dealing with such innovation frameworks corresponding to highly iterative innovation cycles are e.g. agile development, Lean Startup or Design Thinking (Cooper, 2014). These aim to conceptualize a semi-structured, however rather iterative mode of business model innovation. Our study offers a complementary perspective on related research dealing with iterative methodologies. The paper at hand provides evidence for two characteristic decision gates, which companies apply independent of other iterative frameworks companies use. The first decision gate refers to a commitment to test a business model sketch in a test-bed environment. The subsequent decision gate refers to a commitment of the organization to scale the business model. These decision gates may be interpreted as separators to identify chronological phases with activities having distinct characteristics. Hence, while a company might apply iterative approaches (e.g. Lean Startup or Design Thinking) to develop a 'minimum viable product' (MVP) or 'business model pivot' over several iterations, these iterative cycles appear either before, in-between or after the gates identified in this paper. For instance, between gate one and gate two a design thinking workshop series might be applied to develop a MVP to afterwards decide at gate two whether to finally scale up the business model. These findings, and further evidence from the interviews undergone, are inducted for a discussion on the set of characteristic activities before decision gate one, in between, and after decision gate two.

Before gate one, activities contribute to the enhancement of the integrity of qualitative information. Fact-based, objective information to verify the potential financial viability of the projected business model is difficult to assess ex-ante. For example, it is difficult to evaluate different modes of revenue mechanics that aim to exploit the maximum willingness-to-pay for a value proposition. Within the cases investigated, it was not possible to obtain exact numbers for these factors purely based on analytical considerations. Hence, in order to determine key financials for a first business case, the project managers used workshops to collect a best-guess-estimation from industry experts, potential partners and customers. However, the overall statement on potential profitability is dependent on a broad variety of assumptions. Thereby, we observed many times that the project management interpreted the gathered information based on a 'gut-feeling' in order to assemble an overall profit-and-loss estimation as a decision base. Therefore, the integrity of information of these calculations was questioned in many cases by the management board. An important factor with a significant impact on the kill/go decision at gate one stemmed from the story telling ability of the project management. BMI tools that helped to carve out relevant information as outlined in table 2 had an analytical and qualitative characteristic.

Between decision gate one and two, one may access potential customers, partners and suppliers of the business model based on a proof-of-concept business-model-prototype. This allows for new modes of evolving and evaluating different aspects of the business model, such as the consideration of customer journeys, negotiations with potential partners or quantitative customer surveys. With such means, one may then objectify the underlying assumptions of the prototype business model based on real interactions of customers and partners. Other than in the previous phase, these means of evaluation are now rather based on tangible evidence. This also contributes to the reduction of potential financial or 
organizational risks when scaling the business model. Tools for this phase may be characterized by their ability to gather data and information based on interactions with the prototype. Furthermore, these tools test the assumptions underlying the business model, make them less uncertain, and contribute to the integrity of quantitative information for a subsequent scaling decision.

After decision gate two, the major aim is to scale a successfully tested business model design in terms of markets, width of product/service offering and organizational aspects to reach overall financial success. Within this phase, one may observe better ability to standardize activities. Still, compared to NPD, activities and corresponding tooling are of a rather iterative characteristic. Nonetheless, the more advanced the status of IoT BMI projects, the better are traditional tools and metrics of more structured idea-to-launchprocesses suited. As an example, key-performance-indicators (KPIs) gain in importance to evaluate the economic success of business models.

Other than being purely focused on phases (cf. Laudien and Daxböck, 2016a), or only building upon anecdotal evidence from past processes (Frankenberger et al., 2013), the paper at hand focused and clearly identified two major decision gates across the analyzed IoT business model innovation projects. Critically reflecting the findings, we argue that they contribute to scientific research by providing a meta-view on idea-to-launch processes in general, reflecting evidence from real-world IoT business model innovation projects. We suggest that future research may add to the comparability of the multitude of suggested innovation processes and approaches within business model innovation research. Furthermore, we argue that our findings contribute to research endeavors for consolidation. Lastly, research on the aspect of business model tooling profits from requirements and characteristics of activities within the different phases of BMI.

In terms of practical implications, we hope that an enhanced understanding of IoT BMI, will enable practitioners to better orchestrate their activities to strengthen the decision base in diverse IoT BMI projects. The findings emphasize that applying iterative approaches and following a clear procedure with (at least single) fixed gates might not be contradicting in the end. While it allows companies to test and experiment on an ongoing basis, at certain points clear decisions are required. According to the analysis across different types of IoT business model innovation processes two main gates can be identified. Delivering a solid foundation for subsequent publications to a practitioner's audience, we hope to contribute to making the complexity of BMI easier to understand and manage.

\section{Conclusion}

The paper at hand identified two main decision points and the applied decision criteria in IoT business model innovation processes on the basis of 27 expert interviews. In total 13 analyzed case studies included IoT projects from eight leading multinational corporations across the IoT ecosystem. Hence, this study can be seen as a first explorative contribution to a growing literature stream on IoT adoption. The findings are conceptualized by applying the popular launch-to-idea process 'Stage-Gate system' and the underlying core concepts stages and gates. IoT specific hurdles to BMI (e.g. more complex ecosystems, etc.) (Bilgeri and Wortmann, 2017), and faster emerging environmental influences (e.g. shorter technology cycles) in the context of the Internet of Things, lead to a demand for new innovation approaches (i.e. iterative, agile, lean methodologies) and skepticism towards so far widely established launch-to-idea innovation processes. However, the 
results of this study indicate that new iterative innovation approaches and traditional launch-to-idea processes can complement each other. While applying iterative approaches, the majority of companies still rely on at least two main go/kill or prioritization decisions as suggested in traditional innovation process literature. In line with recent publications on how to design BMI processes and how a next generation Stage-Gate system could look like, this paper argues that (advanced) idea-to-launch processes are still of high relevance in practice. For that reason, it is crucial for practitioners and scholars alike to gain a better understanding of the relevant gates and even more about the underlying decision criteria applied. This study and its results need to be assessed in the light of its limitations. A generic limitation of qualitative case-study based research is generalizability. More specifically, the research results are limited by the selection of case studies and the respective interview partners. A comparatively large sample size of 27 experienced professionals from eight multinational organizations across the IoT ecosystem was selected based on a set of predefined criteria. Nevertheless, further studies should be conducted covering other types of companies as well as additional industries. In other words, future work in different empirical settings will be necessary to further improve the validity of the research (cf. Desyllas and Sako, 2013).

This study aims to lay a fruitful ground for future research. Subsequent research avenues might include follow-up studies on the identified decision criteria in BMI processes with regard to their impact on projects' success. Furthermore, an assessment on the validity of tools and methodologies (e.g. Tesch, 2016), may contribute to an enhanced systematization of business model innovation.

\section{References}

Amit, R. and Zott, C. (2001), "Value Creation in E-Business", Strategic Management Journal, Vol. 22 No. 6-7, pp. 493-520.

Arnold, C., Kiel, D. and Voigt, K.-I. (2016), "How the Industrial Internet of Things Changes Business Models in Different Manufacturing Industries", International Journal of Innovation Management, Vol. 20 No. 8, pp. 1640015-1-25.

Atzori, L., Iera, A. and Morabito, G. (2010), "The Internet of Things: A Survey", Computer Networks, Vol. 54 No. 15, pp. 2787-2805.

Baden-Fuller, C. and Morgan, M.S. (2010), "Business Models as Models", Long Range Planning, Vol. 43 No. 2-3, pp. 156-171.

Benbasat, I., Goldstein, D.K. and Mead, M. (1987), "The Case Research Strategy in Studies of Information Systems", MIS Quarterly, Vol. 11 No. 3, pp. 369-386.

Bilgeri, D. and Wortmann, F. (2017), "Barriers to IoT Business Model Innovation", in Leimeister, J.M.; Brenner, W. (Ed.), Proceedings der 13. Internationalen Tagung Wirtschaftsinformatik (WI 2017), St. Gallen, pp. 987-990.

Blaikie, N.W.H. (1991), "A Critique of the Use of Triangulation in Social Research", Quality and Quantity, Vol. 25 No. 2, pp. 115-136.

Blank, S. (2013), "Why the Lean Start-up Changes Everything", Harvard Business Review, Vol. 91 No. 5, pp. 63-72.

Brown, S.L. and Eisenhardt, K.M. (1997), "The Art of Continuous Change: Linking Complexity Theory and Time-Paced Evolution in Relentlessly Shifting Organizations", Administrative Science Quarterly, Vol. 42 No. 1, pp. 1-34. 
Casadesus-Masanell, R. and Zhu, F. (2013), “Business Model Innovation and Competitive Imitation. The Case of Sponsor-Based Business Models", Strategic Management Journal, Vol. 34 No. 4, pp. 464-482.

Cavalcante, S.A. (2014), "Designing Business Model Change", International Journal of Innovation Management, Vol. 18 No. 2, pp. 1-22.

Chesbrough, H. (2010), "Business Model Innovation: Opportunities and Barriers", Long Range Planning, Vol. 43 No. 2-3, pp. 354-363.

Cooper, R.G. (2008), "Perspective: The Stage-Gate ${ }^{\circledR}$ Idea-to-Launch Process-Update, What's New, and NexGen Systems", Journal of Product Innovation Management, Vol. 25 No. 3, pp. 213-232.

Cooper, R.G. (2014), "What's Next?: After Stage-Gate", Research-Technology Management, Vol. 57 No. 1, pp. 20-31.

Cortimiglia, M.N., Ghezzi, A. and Frank, A.G. (2016), "Business Model Innovation and Strategy Making Nexus. Evidence from a Cross-Industry Mixed-Methods Study", $R \& D$ Management, Vol. 46 No. 3, pp. 414-432.

Demil, B. and Lecocq, X. (2010), "Business Model Evolution: In Search of Dynamic Consistency", Long Range Planning, Vol. 43 No. 2-3, pp. 227-246.

Denzin, N.K. and Lincoln, Y. (2000), Handbook of Qualitative Research, 2. ed., Sage Publications, Thousand Oaks.

Desyllas, P. and Sako, M. (2013), "Profiting from Business Model Innovation: Evidence from Pay-As-You-Drive Auto Insurance”, Research Policy, Vol. 42 No. 1, pp. 101116.

Eisenhardt, K.M. (1989), "Building Theories from Case Study Research”, Academy of Management Review, Vol. 14 No. 4, pp. 532-550.

Eisenhardt, K.M. and Graebner, M.E. (2007), "Theory Building from Cases: Opportunities and Challenges", Academy of Management Journal, Vol. 50 No. 1, pp. 25-32.

Fleisch, E., Weinberger, M. and Wortmann, F. (2015), “Geschäftsmodelle im Internet der Dinge”, Schmalenbachs Zeitschrift für betriebswirtschaftliche Forschung, Vol. 67 No. 4, pp. 444-465.

Frankenberger, K., Weiblen, T., Csik, M. and Gassmann, O. (2013), "The 4I-Framework of Business Model Innovation: A Structured View on Process Phases and Challenges", International Journal of Product Development, Vol. 18 No. 3-4, pp. 249-273.

Gephart, R.P. (2004), "Qualitative Research and the Academy of Management Journal”, Academy of Management Journal, Vol. 47 No. 4, pp. 454-462.

Günzel, F. and Holm, A.B. (2013), "One Size Does Not Fit All-Understanding the Front-End and Back-End of Business Model Innovation", International Journal of Innovation Management, Vol. 17 No. 1, pp. 1340002-1-34.

Harmancioglu, N., McNally, R.C., Calantone, R.J. and Durmusoglu, S.S. (2007), "Your New Product Development (NPD) is Only as Good as Your Process: An Exploratory Analysis of New NPD Process Design and Implementation”, $R \& D$ Management, Vol. 37 No. 5, pp. 399-424.

Iansiti, M. and Lakhani, K.R. (2014), "Digital Ubiquity: How Connections, Sensors, and Data Are Revolutionizing Business (Digest Summary)", Harvard Business Review, Vol. 92 No. 11, pp. 91-99.

Koen, P.A., Bertels, H.M.J. and Elsum, I.R. (2011), "The Three Faces of Business Model Innovation. Challenges for Established Firms", Research Technology Management, Vol. 54 No. 3, pp. 52-59. 
Koh, S.L., Gunasekaran, A. and Goodman, T. (2011), "Drivers, Barriers and Critical Success Factors for ERPII Implementation in Supply Chains: A Critical Analysis", The Journal of Strategic Information Systems, Vol. 20 No. 4, pp. 385-402.

Kuckartz, U. (2012), Qualitative Inhaltsanalyse. Methoden, Praxis, Computerunterstützung [Qualitative Content Analysis. Methods, Practice, Computer Assistance], Beltz Juventa, Weinheim and Basel.

Landau, C., Karna, A. and Sailer, M. (2016), "Business Model Adaptation for Emerging Markets. A Case Study of a German Automobile Manufacturer in India”, $R \& D$ Management, Vol. 46 No. 3, pp. 480-503.

Langley, A. (1999), "Strategies for Theorizing from Process Data", The Academy of Management Review, Vol. 24 No. 4, pp. 691-710.

Laudien, S.M. and Daxböck, B. (2016a), "Business Model Innovation Processes of Average Market Players. A Qualitative-Empirical Analysis”, R\&D Management, pp. $1-11$.

Laudien, Sven M., and Birgit Daxböck (2016b), "The Influence of The Industrial Internet of Things on Business Model Design: A Qualitative-Empirical Analysis." International Journal of Innovation Management, Vol. 20, No. 8, pp. 1640014-1-28.

Leonard-Barton, D. (1990), “A Dual Methodology for Case Studies: Synergistic Use of a Longitudinal Single Site with Replicated Multiple Sites”, Organization Science, Vol. 1 No. 3, pp. 248-266.

Leonard-Barton, D. (1992), "Core Capabilities and Core Rigidities: A Paradox in Managing New Product Development”, Strategic Management Journal, Vol. 13 No. 1, pp. 111-125.

Liedtka, J. (2015), "Perspective: Linking Design Thinking with Innovation Outcomes through Cognitive Bias Reduction", Journal of Product Innovation Management, Vol. 32 No. 6, pp. 925-938.

Magretta, J. (2002), "Why Business Models Matter", Harvard Business Review, Vol. 80 No. 5, pp. 86-92.

Markides, C. (2006), "Disruptive Innovation: In Need of Better Theory”, Journal of Product Innovation Management, Vol. 23 No. 1, pp. 19-25.

Mattern, F. and Floerkemeier, C. (2010), "From the Internet of Computers to the Internet of Things", in Hutchison, D., Kanade, T., Kittler, J., Kleinberg, J.M., Mattern, F., Mitchell, J.C., Naor, M., Nierstrasz, O., Pandu Rangan, C., Steffen, B., Sudan, M., Terzopoulos, D., Tygar, D., Vardi, M.Y., Weikum, G., Sachs, K., Petrov, I. and Guerrero, P. (Eds.), From Active Data Management to Event-Based Systems and More, Lecture Notes in Computer Science, Vol. 6462, Berlin, Heidelberg, pp. 242 259.

Mattern, F. and Flörkemeier, C. (2010), "Vom Internet der Computer zum Internet der Dinge", Informatik-Spektrum, Vol. 33 No. 2, pp. 107-121.

Miles, M.B. and Huberman, A.M. (1994), Qualitative Data Analysis: An Expanded Sourcebook, 2. ed., Sage Publications, Thousand Oaks, CA.

Miorandi, D., Sicari, S., De Pellegrini, F. and Chlamtac, I. (2012), "Internet of Things: Vision, Applications and Research Challenges", Ad Hoc Networks, Vol. 10 No. 7, pp. 1497-1516.

Porter, M.E. and Heppelmann, J.E. (2015), "How Smart, Connected Products are Transforming Companies", Harvard Business Review, Vol. 93 No. 10, pp. 96-114.

Ries, E. (2011), The Lean Startup: How Today's Entrepreneurs Use Continuous Innovation to Create Radically Successful Businesses, 1. ed., Crown Business, New York, NY. 
Sarasvathy, S.D. (2001), "Causation and Effectuation: Toward a Theoretical Shift from Economic Inevitability to Entrepreneurial Contingency", Academy of Management Review, Vol. 26 No. 2, pp. 243-263.

Schneider, S. and Spieth, P. (2013), "Business Model Innovation: Towards an Integrated future research agenda", International Journal of Innovation Management, Vol. 17 No. 1, pp. 1340001-1-34.

Schnell, R., Hill, P.B. and Esser, E. (2014), Methoden der Empirischen Sozialforschung, 10. ed., De Gruyter Oldenbourg, Munich.

Teece, D.J. (2010), “Business Models, Business Strategy and Innovation”, Long Range Planning, Vol. 43 No. 2-3, pp. 172-194.

Tesch, J. F. (2016), "Discovering the Role of Scenario Planning as an Evaluational Methodology for Business Models in the Era of the Internet of Things (IoT)", Proceedings of the Twenty-Fourth European Conference on Information Systems (ECIS), Istanbul, Turkey, 2016.

Vermesan, O., Friess, P., Guillemin, P., Sundmaeker, H., Eisenhauer, M., Moessner, K., Le Gall, F. and Cousin, P. (2013), "Internet of Things Strategic Research and Innovation Agenda", River Publishers Series in Communication, pp. 7-151.

Westerlund, M., Leminen, S. and Rajahonka, M. (2014), "Designing Business Models for the Internet of Things", Technology Innovation Management Review, Vol. 4 No. 7 , pp. 5-14.

Wirtz, B.W., Schilke, O. and Ullrich, S. (2010), "Strategic Development of Business Models: Implications of the Web 2.0 for Creating Value on the Internet", Long Range Planning, Vol. 43 No. 2-3, pp. 272-290.

Yin, R.K. (1981), “The Case Study Crisis: Some Answers”, Administrative Science Quarterly, Vol. 26 No. 1, pp. 58-65.

Yin, R.K. (2013), Case Study Research: Design and Methods, 5. ed., Sage Publications, Thousand Oaks.

Zott, C. and Amit, R. (2009), "Business Model Design: An Activity System Perspective", Long Range Planning, Vol. 43 No. 2-3, pp. 216-226.

Zott, C., Amit, R. and Massa, L. (2011), “The Business Model: Recent Developments and Future Research”, Journal of Management, Vol. 37 No. 4, pp. 1019-1042. 